ENVIRONMENTAL AND CLIMATE

TECHNOLOGIES

ISSN 1691-5208

VIDES UN KLIMATA

TEHNOLOĢIJAS

2009-5208

\title{
APPLICATION OF EVALUATION METHOD TO LATVIA'S CLIMATE CHANGE POLICY
}

\section{LATVIJAS KLIMATA PĀRMAIN̦U POLITIKAS NOVĒRTĒJUMS}

S.N.Kalniņš, M.Sc., PhD student

The Institute of Energy Systems and Environment, Riga Technical University Address: Kronvalda bulv. 1, Rīga LV-1010

Phone: +37129141606

e-mail: silvija.kalnins@,rtu.lv

D. Blumberga, Dr.Hab.Sc.Ing.

The Institute of Energy Systems and Environment, Riga Technical University Address: Kronvalda bulv. 1, Rīga LV-1010

Phone: +37129141606

e-mail: dagnija.blumberga@rtu.lv 


\section{Introduction}

The goal of the research is to develop an evaluation methodology appropriate for conducting an evaluation of the climate change polity in Latvia in order to assess its progress. A developmental methodology based on programme evaluations conducted on projects implemented by the United Nations Development Programme in the field of the environment was applied.

\section{Evaluation methodology}

The subject of the evaluation in this research is the climate change policy in Latvia. In preparation of the evaluation methodology to be applied in this evaluation and for the purposes of the research, it was assumed the evaluation to be commissioned by the Ministry of Environment of Latvia for the purposes of providing an independent assessment of results achieved in during the implementation of climate change policy. As a result of the evaluation, it was important to develop recommendations for improving the impact and efficiency of the climate change policy in the interests of the line ministry.

During the research 11 evaluation methodologies were reviewed, their application in the policy process and was compared and the most appropriate evaluation method for the purposes of evaluating the climate change policy in Latvia was selected. Of the evaluation methodologies reviewed, the authors applied a results-based evaluation based on a formative/developmental evaluation methodology. A formative evaluation approach is used for the evaluation with the following steps:

- Document review and analysis (policy programmes and plans, meetings minutes from councils established at the Ministry of Environment related to climate change issues, other documents generated by the Ministry of Environment and its subordinate institutions). Other climate change policy documents were reviewed to provide a general view on different approaches in policy making on climate change;

- Data collection on concrete indicators for results developed within the climate change policy in Latvia and analysis on whether they were achieved;

- Interviews with involved parties.

As seen in Figure 1, the four main criteria are: relevance (conformity to country priorities), efficiency (expected against actual results), efficacy (the efficient use of human and financial resources) and impact (achievement of long-term impact and sustainability). The evaluation criteria used are based on the evaluation approach broadly applied in the assessment of the results and efficiency of environmental and other programmes of the World Bank, the United Nations Development Programme and the Global Environmental Facility. 


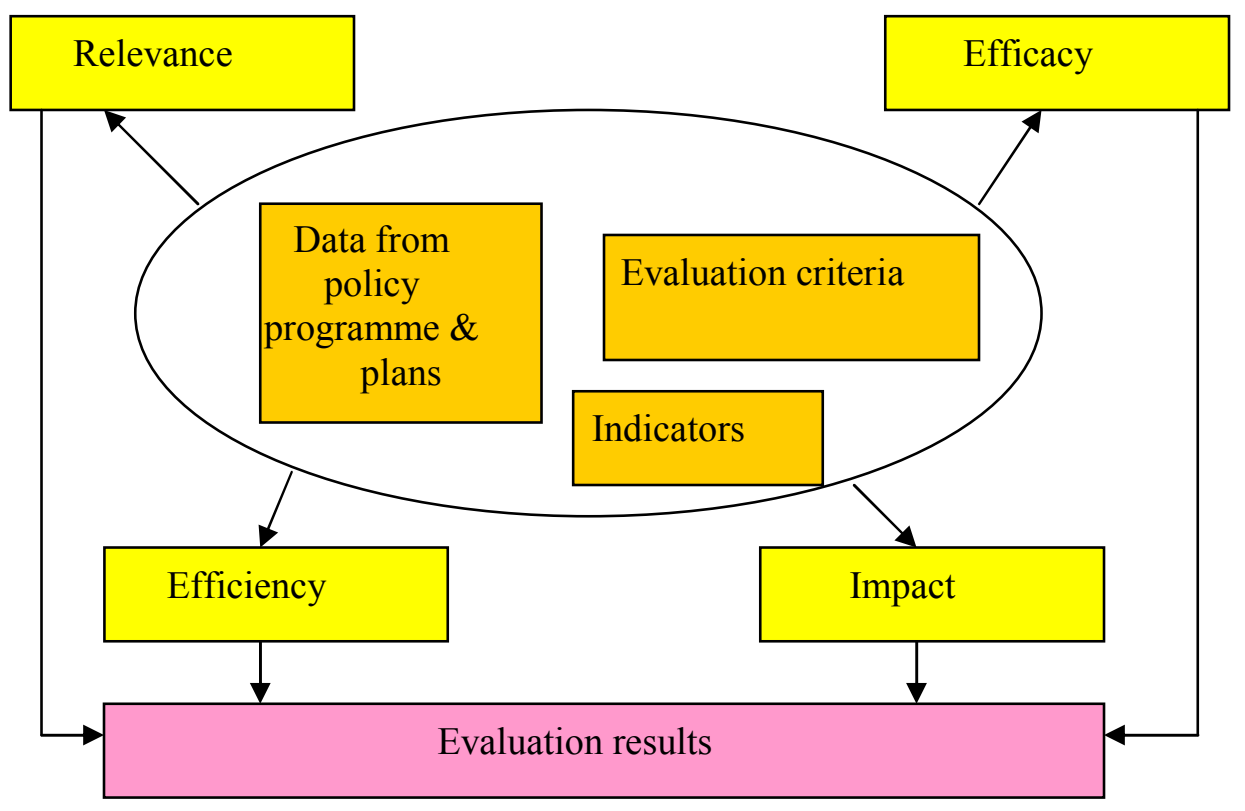

Fig. 1. Evaluation model

For each criterion, several indicators based upon which the climate change policy is evaluated were attributed. The evaluation had to attribute a value of $0-3$ (0 indicating that the indicator was unsatisfactorily met by the policy to the value of 3 which indicated that the policy fully achieved the indicator in question) to each indicator based on the performance of the climate change policy for that indicator. Thus, a value was achieved for each criterion on to what extent the policy performed.

The relevance of the climate change policy was looked at in accordance with the following indicators: conformity of the goals of Latvian climate change policy to international conventions and European Union requirement; the conformity of the climate change policy priorities to national priorities and synergy with policy documents from other sectors (agriculture, transport, economy, etc); clear approach in the structure and implementation of the policy; involvement of various government and other partners in policy implementation; connection between the goals to be obtained by the policy and the needs of the target beneficiaries of the policy, and others.

The criteria efficiency measured indicators related to risk identification and management during the development and implementation of the policy. It also looked at the indicators developed within the policy document and the extent to which these indicators were met during the policy period. The efficacy of the climate change policy was evaluated in accordance with: the effectiveness of its financial reporting and management; the use of monitoring and evaluation of the policy results, the success in cooperating with partner organizations, the implementation of actions on the basis of sound research and others. Finally, the impact of the climate change policy was evaluated on its engagement of society in educational activities and the policy implementation in general, the identification of risk groups during the policy development phase and the integration of actions to minimise any negative impacts on these groups, actions to achieve capacity development of key stakeholders in the policy implementation.

Further, each criterion is given an importance factor which is applied to the value in order to receive the final performance rating for the individual criteria and for the performance of the policy on the whole. The criteria is considered as the most important criteria with an importance factor of 1 and the lowest - relevance with an importance factor of 0,25 .

\section{Results of the research}

The evaluation of the climate change policy in Latvia was primarily centred on evaluating the Climate Change Reduction Programme from 2005-2010, which was adopted on 5 April 2005 by the Cabinet of Ministers of Latvia. In accordance with Latvia's State Chancellery, in the hierarchy of environmental policy documents in Latvia, the Climate Change Reduction Programme is second (in parallel with the National Environmental Policy Plan) in this hierarchy subordinate only to the Basic Principles for Sustainable Development in Latvia. Thus the scope of the evaluation was primarily limited to the evaluation of the abovementioned Programme.

The results of applying the evaluation methodology to the Climate Change (CC) Reduction Programme are reflected in Table 1 below. One of the constraints of 
the evaluation in its application was the inability to make any evaluation of financial management, reporting or efficiency, which is a significant indicator of efficiency of a policy. This matter, however, did not affect the overall rating of the policy in terms of efficiency, as the evaluators did not assume that the lack of transparency on this issue did not automatically indicate poor financial planning and management. This indicator was not taken into consideration under the criterion 'efficiency'.

Evaluation ratings

\begin{tabular}{|c|c|c|c|}
\hline $\begin{array}{r}\text { Evaluation } \\
\text { criteria }\end{array}$ & Rating, \% & Importance factor & Rating, \% \\
\hline Relevance & $83 \%$ & 0,25 & $21 \%$ \\
\hline Efficiency & $58 \%$ & 0,50 & $29 \%$ \\
\hline Efficacy & $50 \%$ & 1,0 & $50 \%$ \\
\hline Impact & $50 \%$ & 0,75 & $37 \%$ \\
\hline \multicolumn{2}{|r|}{ Overall rating: } & $34,2 \%$ \\
\hline
\end{tabular}

In accordance with the authors' evaluation methodology and selected indicators, Latvia's climate change policy performance rating is high for the criterion relevance. The policy is successful in integrating international and EU goals and in providing a framework which integrates the cross-sectoral nature of climate change within one policy document. Effectiveness is also rated well as the policy implementation process has succeeded in reaching (in some cases exceeding) the goals set by the policy. The political results to be achieved by the policy are the development of political planning documents and regulations related to climate change. These political results are achieved producing, in the first two years, five of the targeted five planning documents and seven legal acts in the span of time when only five were set as a target. Although this indicates that the climate change policy is producing the political documents that it was targeted to produce, the evaluation does question on whether these results indicators are indicators of results or process. Among the seventeen results listed in the CC Reduction Programme on the operational level, many of the results are also achieved (or exceeded) but, again, the indicators selected in some cases (number of projects implemented, number of companies adopting ISO 14001 standards, number of research and campaigns conducted) place the emphasis for measuring the success of the policy implementation on processes, rather than results. This general issue surrounding the indicators selected within the policy document is one of the problems in advancing the monitoring and evaluation of policy documents of this scale in Latvia. By concentrating the development and implementation of policies on processes, the ability of these policies to produce impact is limited. In turn, the civil servant measuring progress of the policy document, through the use of process indicators, is not provided with information on whether this process is producing the necessary results for which the policy is intended. Furthermore, professional associations, nongovernmental organisation and the general public can request accountability from the Government only on the basis of the process and not the long-term results or impact needed. Lastly, such indicators, in the long-term do not provide a clear picture on whether the concrete policy is having an effect on the environment or changing the behaviour of individuals needed to preserve the environment.

The climate change policy in Latvia, however, has lower ratings on efficacy and impact, which is primarily based on the need to improve the effective use of human resources. There is also reason to believe that, by increasing the transparency of financial resource management, the efficiency of this resource could also be improved. There are five councils established under the Ministry of Environment which, according to their designated tasks, could be providing more support to the administration during the policy development and implementation process. By applying results-oriented policy monitoring, it would be possible to increase the adaptability of policy to the changing environment and financial resources, increase involvement in the policy process and to increase transparency. The climate change policy identifies particular actions for parties involved in the implementation only in the realm of the government sector. Although the policy mentions over ten other partners beyond the line ministries and their subordinate institutions such as municipalities (particularly the capital city of Riga), private sector representatives, the general public, researchers, 
educators, etc, there are is no strategy on their 2. involvement in the climate change policy implementation and appears to have been little input 3 . from these parties in the policy development. It was noted during the evaluation that the development of Latvia's Climate Change Reduction Programme from 2005-2010 did not include a strategic environmental impact assessment (SEA) of the programme as could be called for in accordance to the level of the policy document. A decision was made by the Environmental State Bureau of Latvia that the SEA procedure need not be applied to this particular policy. There was no evidence found during the evaluation that nongovernmental organizations or other interested parties outside of the Government authorities were involved in the development of the policy.

By integrating results-oriented monitoring and evaluation tools into the policy development and implementation processes, such as risk assessment and management, priority setting, target groups needs assessment would assist the administration to structure strategies for policy implementation and maximise resource mobilization opportunities. Adapting the process indicators contained in Latvia's Climate Change Reduction Programme from 2005-2010 (such as number of legal acts and political plans and programmes approved, number or projects implemented, research and public information events conducted) to reflect results, rather than processes would make it possible to support actions that would provide the Ministry of Environment and its departments with additional information, data and resources to reach the policy objectives in climate change.

On 3 June 2008 a Cabinet of Ministers' Decree on the Basic Plan for the Development of National Governance Policies (2008-2013) was adopted which foresees the development of forward-looking strategic planning policies, including the improvement of the financial management and strategic planning systems. This new Government decree and the fact that the Climate Change Reduction Programme is coming to its end in 2010 makes it an opportune time to integrate results-based monitoring and evaluation systems into the development of climate change policy in the next policy development and implementation cycle from 2010 onwards.

\section{References}

1. Ann Crabbe, Pieter Leroy. The Handbook of Environmental Policy Evaluation. Earthscan, 2008. - P.45-138.
UNDP Handbook on Monitoring and Evaluating for results. UNDP Evaluation Office, 2002. - P. 8-112. Informatīvais ziņojums par Klimata pārmainu samazināšanas programmas 2005.-2010.gadam izpildi. 16.03.2007.

\begin{abstract}
Silvija Nora Kalniņš, Dagnija Blumberga, Latvijas klimata pārmaiņu politikas novērtējums

Darba mērkis ir izstrādāt metodiku vides politikas vērtēšanā un pielietot to, vērtējot Latvijas klimata pārmaiņu politiku. Darba izklāsts par novērtējuma piemēriem un to iespējamo nozīmi politikas veidošanas un ieviešanas procesā ir balstīts uz literatūras analīzi, $k \bar{a}$ arī uz Latvijas pieredzi Apvienoto Nāciju Organizācijas Attīstības programmā, projektu un programmas vērtēšanā, vides programmas ieviešanā Latvijā.

Vērtēšanas kritēriji ir būtiskums (atbilstība valsts prioritātēm), rezultativitāte (iepriekš-nosprausto rezultātu sasniegšana), efektivitāte (politikas ieviešanas procesa cilvēku un finanšu resursu efektīvā izmantošana) un ietekme (ilgtermiņa rezultātu sniegšana un ilgtspējības nodrošināšana). Katram kritērijam ir vairāki indikatori, pēc kuriem klimata pārmainga politika tiek vērtēta, lai iegūtu vērtību par kritērija sasniegšanu. Tālāk katram kritērijam piešksirts svarīguma koeficients, kur kritērijs ,,efektivitāte” tiek noteikts, kā vissvarīgākais faktors (ar koeficientu 1) un kritērijs ,bütiskums”zemākais svarīguma koeficents $(0,25)$.
\end{abstract}

Silvija Nora Kalnins, Dagnija Blumberga, Application of evaluation method to Latvia's climate change policy

The goal of the research is to develop a methodology for a policy evaluation and apply it to the climate change policy in Latvia, applying information and experience from the United Nations Development Programme in Latvia in the implementation of its environmental portfolio.

The evaluation criteria used are: relevance (conformity to country priorities), efficiency (expected against actual results), efficacy (the efficient use of human and financial resources) and impact (achievement of long-term impact and sustainability). Each criterion has several indicators based upon which the climate change policy is evaluated and a value on the performance of the policy is attributed for each criteria. Further, each criterion is given an 
importance factor which is applied to the value in order to receive the final performance rating for the individual criteria and for the performance of the policy on the whole.

Силвия Нора Калниньш, Дагния Блумберга, Оценка политики Латвии в сфере изменения климата

Целью данного исследования является разработка методики для оченки политик в области охрань окружающей среды и апробачии данной методики для оценки политики Латвии в сфере изменения климата. Изложенные в работе примеры оченок и возможное их влияние на формирование и внедрение политики, основано на анализе литературных источников, а также на опыте Латвии в осуществлении деятельности Программы развития Организачии Объединенных Наџий, оченки проектов и программ, в том числе Программы по охране окружающей среды Латвии.

В работе использовались следующие оченочные критерии: существенность (соответствие государственным приоритетам), результативность (достижение прежде поставленных иеелей), эффективность (эффективное использование кадровых и финансовых ресурсов для реализации политики) и влияние (долгосрочная результативность $и$ обеспечение принципов долгосрочного развития).Каждый критерий включает в себя несколько индикаторов, по которым оценивается политика в области изменения климата, для достижения значения определённого критерия. Далее каждому критерию присваивается коэффициент значимости: критерию "эффективность" присвоен выстий коэффициент значимости, равный единице, а критерию "существенность" - низиий коэффициент, равньй 0,25 . 